P-ISSN: $1979-0724$

E-ISSN: 2502-3993

DOI: http://dx.doi.org/10.21043/iqtishadia.v10i1.2316

Volume 10 Nomor 12017

\title{
METODE SPIN-OFF DAN TINGKAT PROFITABILITAS: STUDI PADA BANK UMUIM SYARIAH HASIL SPIN-OFF
}

\author{
M Nur Rianto Al Arif, Endah Putri Dewanti \\ Universitas Islam Negeri (UIN) Syarif Hidayatullah Jakarta \\ nur.rianto@uinjkt.ac.id, endahputri@gmail.com
}

Abstrak

Undang-undang No. 21 tahun 2008 tentang Perbankan Syariah mewajiban setiap unit usaha syariahuntukmelakukan pemisahan apabila telah memenuhi kriteria. Terdapat dua metode pemisahan yang dapat dipilih oleh bank syariah. Tujuan dari penelitian ini ialah untuk menganalisis pengaruh metode pemisahan terhadap tingkat profitabilitas. Sampel yang digunakan pada penelitian ini adalah empat bank syariah hasil pisah. Indikator profitabilitas yang dipergunakan dalam penelitian ini ialah rasio return on asset. Metode analisis yang dipergunakan dalam penelitian ini regresi panel dengan model efek acak. Hasil penelitian menunjukkan bahwa metode pemisahan tidak berdampak pada tingkat profitabilitas di bank umum syariah hasil pemisahan, hanya tingkat efisiensi operasional (BOPO) dan tingkat pembiayaan bermasalah (NPF) yang berdampak pada tingkat profitabilitas.. Hasil ini mengindikasikan bahwa unit usaha syariah yang ingin memisahkan diri dapat memilih metode pemisahan. Keputusan tergantung pada kondisi internal dari unit usaha syariah dan kebijakan internal dari bank induk konvensional.

Kata Kunci: metode pemisahan, unit usaha syariah, regresi panel, profitabilitas 


\section{Abstract}

The Law No. 21 of 2008 about Islamic banking, requires every Islamic business unit to spin-off if they have met the criterion. There are two spin-off's methods can be selected by Islamic banks. The purpose of this research is to analyze the effect of spin-off method to profitability. The profitability indicator that used in this study is the return on asset. This study is using panel regression with random effect model. The result showed that spin-off method doesn't have a significant impact on the Return On Asset (ROA) Islamic Banks from spin-offeffect. Only BOPO and Non-Performing Finance (NPF) had a significant effect on Return On Asset (ROA). These results indicate that the Islamic business units that want to do the spin-off can choose one of two methods of the spin-off. The decision depends on the internal condition of Islamic business unit and the internal policies of conventional commercial banks.

Keywords : spin-off's method, Islamic banking unit, panel regression, profitability 


\section{PENDAHULUAN}

Perbankan syariah di Indonesia saat ini sudah beranjak memasuki usia yang semakin matang. Dengan usia yang semakin matang maka langkah-langkah perbaikan dalam pengembangan industri perbankan syariah pun mengalami berbagai proses, terutama pada peraturan dan kebijakan pemerintah. Hal ini dilakukan sebagai upaya pemerintahdalammeningkatkan pangsa pasar bank syariah di Indonesia, karena sampai saat ini pangsa pasar bank syariah masih di bawah 5\%. Salah satu upaya pemerintah adalah diberlakukannya UU No. 21 Tahun 2008 pada tanggal 16 Juli 2008 yang mengatur tentang Perbankan Syariah di Indonesia. Salah satu isu krusial dalam hukum ini adalah tentang adanya aturan-aturan mengenai kebijakan pemisahan unit usaha syariah miliki bank konvensional sebagai bank induknya menjadi bank syariah tersendiri. Adapun kriteria-kriterianya sebagaimana yang tertuang dalam pasal 68 ayat 1, yakni bahwa Bank Umum Konvensional yang memiliki UUS yang nilai asetnya telah mencapai paling sedikit $50 \%$ dari total nilai aset bank induknya atau 15 tahun setelah berlakunya UU No. 21 Tahun 2008 ini yaitu tahun 2023, maka Bank Umum Konvensional yang memiliki UUS wajib melakukan pemisahan UUS tersebut menjadi Bank Umum Syariah (BUS) tersendiri.

Setelah disahkannya UU No. 21 Tahun 2008, muncul trend baru pembentukan bank syariah yang implementasinya dapat dilakukan melalui dua metode pemisahan unit usaha syariah menjadi bank umum syariah. Pertama, bank umum konvensional yang telah memiliki UUS mengakuisisi bank yang relatif kecil kemudian mengkonversinya menjadi berbasis syariah kemudian melepaskan dan menggabungkan UUS-nya dengan bank yang baru dikonversi tersebut menjadi bank umum syariah. Kedua, bank umum konvesional melakukan pemisahan terhadap UUS miliknya dan dijadikan bank umum syariah tersendiri.

Kebijakan pemisahan ini merupakan sebuah upaya pemerintah untuk meningkatkan pangsa pasar bank syariah. Namun, sejak diberlakukannya UU No.21/2008 hingga tahun 2015 pangsa pasar perbankan syariah di Indonesia masih belum mencapai 5\%. Berdasarkan data statistik perbankan syariah mencatat pada tahun 2009 pangsa pasar bank syariah di Indonesia sebesar 2,61\%, tahun 2010 sebesar 3,24\%, tahun 2011 sebesar 3,98\%, tahun 2012 sebesar 
4,58\%, tahun 2013 sebesar 4,89\%, tahun 2014 sebesar 4,85\%, dan hingga Desember 2015 pangsa pasar perbankan syariah masih sebesar $4,83 \%$ dari total aset perbankan secara nasional. (Data Statistik Perbankan Syariah OJK, 2015). Umam (2010) menyatakan bahwa salah satu alasan kebijakan pemisahan ini ialah diharapkan bank syariah lebih taat terhadap prinsip syariah dalam operasional perbankannya.

Tabel 1. Rata-rata BOPO BUS Hasil Pemisahan

Setelah Pemisahan, (\%)

\begin{tabular}{|l|c|c|c|c|c|c|c|c|}
\hline & $\mathbf{2 0 0 8}$ & $\mathbf{2 0 0 9}$ & $\mathbf{2 0 1 0}$ & $\mathbf{2 0 1 1}$ & $\mathbf{2 0 1 2}$ & $\mathbf{2 0 1 3}$ & $\mathbf{2 0 1 4}$ & $\mathbf{2 0 1 5}$ \\
\hline BNI Syariah & - & - & 168,85 & 78,02 & 88,46 & 83,85 & 90,03 & 90,41 \\
\hline BJB Syariah & - & - & 103,84 & 84,94 & 92,53 & 81,67 & 95,05 & 100,31 \\
\hline BRI Syariah & 215,58 & 89,17 & 96,30 & 96,49 & 88,28 & 87,28 & 97,35 & 94,43 \\
\hline $\begin{array}{l}\text { Bukopin } \\
\text { Syariah }\end{array}$ & 187,84 & 112,5 & 93,90 & 93,99 & 93,36 & 91,43 & 97,00 & 94,00 \\
\hline
\end{tabular}

Sumber : Data diolah dari Laporan Keuangan Bank

Sejak tahun 2008-2015 sudah ada 12 bank umum syariah yang beroperasi di Indoensia. Sampai saat ini bank umum konvensional yang memiliki Unit Usaha Syariah (UUS) terus melakukan usaha untuk melakukan pemisahan terhadap unit usahanya dan mungkin untuk kedepannya akan muncul bank-bank umum syariah baru yang terbentuk melalui pemisahan. Untuk melakukan pemisahan dibutuhkan kesiapan dari unit usaha syariah untuk memisahkan diri dari bank induknya. Ketika unit usaha syariah tersebut telah memisahkan diri dan menjadi bank umum syariah tersendiri, biaya-biaya operasional yang awalnya ditanggung oleh bank induk konvensional harus ditanggung sendiri oleh bank syariah hasil pemisahan tersebut. 
II tahun 2010 nilai BOPO mencapai 117,04\%, BRI Syariah pada periode pertama setalah pemisahan yakni kuartal IV tahun 2008 nilai BOPO mencapai 215,58\%, dan Bukopin Syariah pada periode awal setelah pemisahan yakni dikuartal IV tahun 2008 nilai BOPO mencapai $187,84 \%$. Dengan tingginya nilai BOPO pada periode pertama pemisahan menandakan bahwa sangat rendahnya tingkat efisiensi operasional bank umum syariah hasil pemisahan pada periode pertama setelah pemisahan. Hal ini memberi arti bahwa setelah dilakukannya pemisahan, kondisi bank syariah menjadi kurang efisien daripada kondisi sebelum dilakukan pemisahan, yang ditandai dengan tingginya nilai $\mathrm{BOPO}$. $\mathrm{Al}$ Arif (2015) menunjukkan bahwa naiknya nilai BOPO dipengaruhi oleh adanya tambahan biaya operasional yang selama ini ditanggung oleh bank induk konvensional kini harus ditanggung sendiri oleh bank umum syariah hasil pemisahan tersebut.

Data menunjukan bahwa pada pertumbuhan aset, tahun 2011 pertumbuhan aset mencapai $49,17 \%$ lalu pada tahun 2012 pertumbuhannya mulai mengalami penurunan menjadi sebesar $34,06 \%$, hal tersebut terus berlanjut hingga pada tahun 2015 pertumbuhan aset semakin rendah yakni sebesar $8,78 \%$. Pada sisi DPK juga mengalami penurunan laju pertumbuhan, tahun 2011 pertumbuhan DPK mencapai 50,56\% dan di tahun 2012 pertumbuhannya mulai menurun menjadi sebesar $43,69 \%$ di tahun-tahun berikutnya pun mengalami penurunan, kemudian pada tahun 2015 pertumbuhan DPK melambat menjadi sebesar $6,85 \%$. Sama halnya pada sisi pembiayaan, pada tahun 2011 pembiayaan mengalami peningkatan pertumbuhan sebesar $51,80 \%$ namun di tahun 2012 mulai menurun menjadi sebesar $27,81 \% \quad$ kemudian penurunan laju pertumbuhan terus terjadi sampai pada tahun 2015 pertumbuhan pembiayaan semakin rendah yakni sebesar $6,11 \%$. Berdasarkan data di atas, jika diihat dari jumlah aset, DPK, dan pembiayaan selalu mengalami peningkatan setiap tahunnya, namun mulai tahun 2012 pertumbuhan baik dari sisi aset, DPK, maupun pembiayaan mengalami penurunan laju pertumbuhan, padahal pada tahun-tahun sebelumnya selalu mengalami peningkatan. Hal ini berarti telah terjadi penurunan kinerja industri perbankan syariah di Indonesia sejak tahun 2012, padahal seharusnya dengan adanya kebijakan pemisahan diharapkan dapat meningkatkan kinerja perbankan syariah secara nasional. 
Setelah dikeluarkannya UU No. 21 Tahun 2008, banyak unit usaha syariah memisahkan diri dari bank induk konvensional dan menjadi bank umum syariah tersendiri dengan alasan ingin memajukan industri perbankan syariah di Indonesia. Dari sembilan bank umum syariah yang berdiri pasca dikeluarkannya UU No. 21 Tahun 2008 hanya lima BUS yang melalui proses pemisahan UUS.

Tabel 2. Rasio Keuangan BUS Hasil Pemisahan Tahun 2011-2015, (\%) melakukan pemisahan murni yakni BNI Syariah dan BJB Syariah, dan tiga bank lainnya melalui proses akuisisi, konversi, dan merger yaitu BRI Syariah, Bukopin Syariah dan BTPN Syariah pada tahun 2014. Berikut data rasio keuangan empat Bank Umum Syariah Hasil Pemisahan.

\begin{tabular}{|c|c|c|c|c|c|c|}
\hline & & 2011 & 2012 & 2013 & 2014 & 2015 \\
\hline \multirow{5}{*}{ BNIS } & ROA & 1,29 & 1,48 & 1,37 & 1,27 & 1,43 \\
\hline & NPF & 2,42 & 1,42 & 1,13 & 1,04 & 1,46 \\
\hline & BOPO & 87,86 & 85,39 & 83,94 & 89,80 & 89,63 \\
\hline & CAR & 20,67 & 14,10 & 16,23 & 18,43 & 15,48 \\
\hline & FDR & 78,60 & 84,99 & 97,86 & 92,60 & 91,94 \\
\hline \multirow{5}{*}{ BJBS } & ROA & 1,23 & 0,67 & 0,91 & 0,72 & 0,25 \\
\hline & NPF & 0,41 & 2,10 & 1,16 & 3,87 & 4,45 \\
\hline & BOPO & 84,07 & 90,62 & 85,76 & 91,01 & 98,78 \\
\hline & CAR & 30,29 & 21,73 & 17,99 & 15,78 & 22,53 \\
\hline & FDR & 78,10 & 88,06 & 97,40 & 84,02 & 104,75 \\
\hline \multirow{5}{*}{ BRIS } & ROA & 0,20 & 1,19 & 1,15 & 0,08 & 0,76 \\
\hline & NPF & 2,12 & 1,84 & 3,26 & 3,65 & 3,89 \\
\hline & BOPO & 99,25 & 86,63 & 95,24 & 99,77 & 102,70 \\
\hline & CAR & 14,74 & 11,35 & 14,49 & 12,89 & 13,94 \\
\hline & FDR & 90,55 & 103,07 & 102,70 & 93,90 & 84,16 \\
\hline \multirow{5}{*}{ BSB } & ROA & 0,52 & 0,55 & 0,69 & 0,27 & 0,79 \\
\hline & NPF & 1,54 & 4,26 & 3,68 & 3,34 & 2,74 \\
\hline & BOPO & 93,86 & 91,59 & 96,73 & 96,77 & 91,99 \\
\hline & CAR & 15,29 & 12,78 & 11,10 & 14,80 & 16,31 \\
\hline & FDR & 83,66 & 92,29 & 100,29 & 92,89 & 90,56 \\
\hline
\end{tabular}

Sumber : Laporan Publikasi Bank, Otoritas Jasa Keuangan, 2015 
Tabel 2 merupakan kinerja keuangan Bank Umum Syariah hasil pemisahan periode 2011-2015. BNI Syariah selama periode 2011-2015 secara umum cenderung mengalami kenaikan kinerja, hal ini dapat dilihat pada meningkatnya nilai $\mathrm{ROA}$ pada tahun 2015, dan meningkatnya tingkat efisiensi yang ditandai dengan menurunnya nilai BOPO di tahun 2015 walau sempat mengalami kenaikan ditahun 2014. Dari sisi NPF mengalami peningkatan di tahun 2015 meski begitu secara umum dari tahun 2011-2014 nilai NPF selalu menurun. BJB Syariah pada periode 20112015 cenderung mengalami penurunan kinerja, hal ini dapat dilihat dari menurunnya tingkat profitabiltas yang diindikasikan darimenurunnya nilai ROA pada dua tahun terakhir. Tidak hanya itu, di tahun 2015 juga terjadi penurunan tingkat efisiensi operasional, meningkatnya pembiayaan bermasalah, dan menurunnya tingkat likuiditas yang ditandai dengan meningkatnya nilai $\mathrm{BOPO}$ dan NPF serta menurunnya nilai FDR. Pada BRI Syariah periode 2011-2015 cenderung mengalami penurunan kinerja, hal ini dilihat dari meningkatnya nilai NPF dan BOPO pada tiga tahun terakhir. Serta terjadi penurunan tingkat likuiditas yang ditandai dengan menurunnya nilai FDR. Dan pada Bukopin Syariah di periode 2011-2015 mengalami peningkatan kinerja, hal ini dapat dilihat dari meningkatnya nilai ROA di tahun 2015 dan dari sisi permodalan juga mengalami peningkatan yang ditandai dengan meningkatnya nilai CAR pada dua tahun terakhir. Pembiayaan bermasalah juga semakin menurun yang ditandai dengan semakin rendahnya nilai NPF di tiga tahun terkahir.

Berdasarkan kinerja Bank Umum Syariah hasil pemisahan dalam kurun waktu lima tahun terakhir dapat dijelaskan bahwa dalam melakukan pemisahan dari UUS menjadi BUS tidak selalu mengalami peningkatan kinerja tetapi juga terdapat BUS hasil pemisahan yang mengalami penurunan kinerja, baik itu dengan cara pemisahan murni maupun melalui akuisisi dan konversi. Terdapat beberapa penelitian yang telah dilakukan terkait kebijakan pemisahan.

Nasuha (2012) melakukan penelitian pada tahun 2010-2011 terkait pengaruh pemisahan terhadap kinerja bank syariah, dalam studinya menunjukkan bahwa perbedaan kinerja antara satu tahun sebelum dan satu tahun sesudah pemisahan terjadi pada total aset, dana pihak ketiga, dan pembiayaan. Hamid (2015) dalam penelitiannya menemukan bahwa kebijakan pemisahan berpengaruh positif terhadap profitabilitas industri perbankan syariah di Indonesia. 
Hal yang sama juga ditunjukkan pada penelitian yang dilakukan Ramdani (2015) bahwa kebijakan pemisahan berpengaruh positif terhadap jumlah laba operasional PT Bank BNI Syariah. Al Arif (2015) melakukan penelitian terkait kebijakan pemisahan dan dampaknya terhadap tingkat efisiensi, dalam penelitiannya menunjukkan bahwa kebijakan pemisahan berpengaruh negatif tehadap efisiensi industri perbankan syariah di Indonesia. Sementara Al Arif (2014) dalam studinya terkait dampak pemisahan tehadap pembiayaan menemukan bahwa kebijakan pemisahan tidak memiliki pengaruh terhadap pertumbuhan pembiayaan bank umum syariah hasil pemisahan. Selain itu, Al Arif (2014) dalam studinya terkait tipe pemisahan dan pengaruhnya terhadap nilai aset menemukan bahwa tipe pemisahan tidak berpengaruh terdahap nilai aset bank umum syariah hasil pemisahan.

\section{KAJIAN LITERATUR}

Pemisahan diperkenalkan melalui Undang-undang No. 40 Tahun 2007 tentang Perseroan Terbatas dan Undang-undang No. 21 Tahun 2008 tentang Perbankan Syariah. Dalam Undang-undang Perseroan Terbatas, pemisahan diartikan sebagai perbuatan hukum yang dilakukan oleh Perseroan untuk memisahkan usaha yang mengakibatkan seluruh aktiva dan pasiva Perseroan beralih karena hukum kepada satu Perseroan atau lebih atau sebagian aktiva dan pasiva Perseroan beralih karena hukum kepada satu Perseroan atau lebih. Dalam Undangundang Perbankan Syariah, kasus pemisahan ini diartikan sebagai pemisahan usaha dari satu bank menjadi dua badan usaha atau lebih, sesuai dengan ketentuan peraturan perundangundangan.

Nasuha

menjelaskan bahwa spinoff menggambarkan suatu tambahan atau produk derivatif atau turunan atau hasil dari sesuatu tiruan usaha sebelumnya. Pemisahan ini bisa berbeda bentuk, tapi umumnya memerlukan perubahan yang penting pada kontrol, risiko, dan distribusi keuntungan. Rizqullah (2013) mengartikan spin-off sebagai upaya pemisahan atau pengalihan sebagian aset perusahaan yang kemudian menjadi perusahaan independen, sementara perusahaan yang melakukan pemisahan atau pengalihan masih tetap beroperasi dan menjadi perusahaan induk dari perusahaan independen tersebut yang disebut juga perusahaan anak. Perusahaan 
induk memiliki kontrol terhadap perusahaan anak dan saham keduanya dimiliki oleh pemegang saham perusahaan induk.

Pembentukan bank
syariah implementasinya
dapat dilakukan melalui dua
metode pemisahan unit usaha
syariah menjadi bank umum
syariah. Pertama, bank umum
konvensional yang telah
memiliki UUS mengakuisisi
bank yang relatif kecil
kemudian mengkonversinya
menjadi berbasis syariah
kemudian melepaskan dan
menggabungkan UUS-nya
dengan bank yang baru
dikonversi tersebut menjadi
bank umum syariah, contohnya:
BRI Syariah dan Bank Bukopin
Syariah. Kedua, bank umum
konvesional melakukan
pemisahan terhadap UUS
miliknya dan dijadikan bank
umum syariah tersendiri, ini
yang dikenal sebagai pemisahan
murni, yaitu BNI Syariah dan
BJB Syariah.

Kiswono

melakukan kajian terhadap roadmap pemisahan yang disusun oleh UUS. Berdasarkan kajian yang dilakukan dapat disimpulkan bahwa rencana pemisahan yang diajukan oleh masing-masing bank tidak selalu dapat digunakan sebagai acuan. Hanya beberapa bank saja yang rencana pemisahannya cukup beralasan untuk dapat direalisasikan. Beberapa bank lain terlihat sangat optimis dalam merencanakan waktu pemisahannya, namun jika melihat potensinya sangat sulit untuk dilaksanakan, dan sebaliknya terdapat juga beberapa bank yang sangat konversatif dalam merencanakan pemisahannya hingga mendekati batas akhir padahal kemampuan permodalannya sudah cukup memadai.

\section{Kiswono}

mengelompokkan

masing bank tersebut berdasarkan potensi permodalanya, yaitu: (i) Modal induk di atas $R p 2$ trilyun dan modal UUS di atas Rp 500 milyar, sehingga secara ketentuan telah memenuhi persyaratan permodalan dan diharapkan dapat segera melakukan pemisahan UUS. Bank-bank yang masuk dalam kelompok ini adalah BTN, Bank Permata, CIMB Niaga, dan Bank Danamon. (ii) Modal induk di atas Rp 2 trilyun namun modal UUS masih dibawah Rp 500 milyar, sehingga masih memerlukan upaya dan waktu yang lebih lama untuk menambah modal UUS nya agar mencapai persyaratan minimal sebesar Rp 500 milyar. Terdapat 5 bank yang memenuhi kriteria 
tersebut yaitu: BII, BTPN, OCBC-NISP, HSBC, Bank Jatim. (iii) Modal induk masih di bawah $\operatorname{Rp} 2$ trilyun namun lebih dari Rp 1 trilyun, sehingga memerlukan upaya yang lebih besar karena harus menambah modal induknya agar mencapai Rp 2 trilyun, maupun untuk menambah modal UUS-nya. Bank yang masuk dalam kategori ini ialah: BPD Jateng, BPD Banda Aceh, BPD Sumut, Bank DKI, Bank Sinarmas, BPD Riau, BPD Sumsel \& Babel, BPD Sumbar, dan BPD Jambi. (iv) Modal induk dibawah $\mathrm{Rp}$ 1 trilyun, sehingga sangat sulit untuk memenuhi kewajiban melakukan pemisahan. Bank yang masuk dalam kategori ini ialah BPD Kaltim, BPD Kalsel, BPD Kalbar, BPD Sulsel, BPD NTB dan BPD DIY.

Siswantoro (2014) dalam artikelnya yang menganalisis tentang kinerja bank syariah dan strategi setelah pemisahan sebagai bank syariah yang mandiri di Indonesia, menjelaskan bahwa suntikan permodalan dari bank induk konvensional seharusnya dapat dimanfaatkan secara optimal untuk dapat meningkatkan pertumbuhan bank syariah hasil pemisahan. Namun, tetap harus didukung dengan manajemen yang efektif pada bank umum syariah hasil pemisahan.

Hamid (2015) pada hasil penelitiannya tekait dampak pemisahan terhadap profitabilitas pada industri perbankan syariah di Indonesia, memaparkan bahwa kebijakan pemisahan yang diterapkan untukindustriperbankansyariah di Indoensia mempunyai efek yang baik untuk meningkatkan profitabilitas yang diukur dengan rasio Return On Asset (ROA). Sama halnya pada penelitian yang dilakukan $\mathrm{Al}$ Arif (2014) terkait pemisahan dan dampaknya terhadap dana pihak ketiga pada industri perbankan syariah di Indonesia, hasilnya menerangkan bahwa kebijakan pemisahan memiliki dampak yang baik untuk meningkatkan dana pihak ketiga industri perbankan syariah di Indonesia. Namun dari aspek efisiensi operasional Al Arif (2015) menjelaskan bahwa terdapat pengaruh antara kebijakan pemisahan terhadap tingkat efisiensi operasional yang diukur dengan rasio Biaya Operasional terhadap Pendapatan Operasional (BOPO) pada bank umum syariah, dimana kebijakan pemisahan justru menurunkan tingkat efisiensi operasional pada industri perbankan syariah di Indonesia. Hal ini menunjukkan bahwa setelah kebijakan pemisahan jsutru mengakibatkan industri perbankan syariah menjadi kurang efisien dibandingkan sebelum kebijakan pemisahan tersebut dilakukan. 


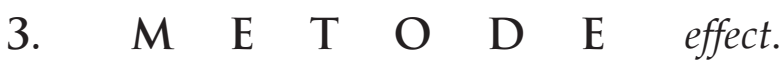

\section{PENELITIAN}

Penelitian

ini menggunakan uji regresi data panel untuk menguji spesifikasi model dan kesesuaian teori-teori dengan kenyataan. Regresi data panel dapat dilakukan melalui tiga pendekatan antara lain: (1) Model common effect; (2) Model fixed effect (efek tetap); (3) Model random effect (efek acak).

Dalam menentukan estimasi model regresi panel, dilakukan beberapa uji untuk memilih metode pendekatan estimasi yang sesuai. Terdapat beberapa pengujian yang dilakukan, antara lain. Pertama, uji chow dilakukan untuk mengetahui apakah model yang digunakan adalah common effect atau fixed effect. Hipotesis uji chow dalam penelitian ini adalah:

$\mathrm{H}_{0}$ : Common Effect Model (CEM)

$$
\mathrm{H}_{1} \text { : Fixed Effect Model (REM) }
$$

Dengan ketentuan jika probabilitas $>0,05$, maka $\mathrm{H}_{0}$ diterima, artinya model yang tepat adalah dengan menggunakan pendekatan common effect. Tetapi jika probabilitas < 0,05, maka $\mathrm{H}_{0}$ ditolak dan menerima $\mathrm{H}_{1}$, artinya model yang tepat adalah dengan menggunakan pendekatan fixed
Kedua, uji Hausman digunakan untuk menentukan apakah model yang paling tepat digunakan adalah model fixed effect atau model random effect. Hipotesis uji hausman dalam peneltian ini adalah:

\section{$\mathrm{H}_{0}$ : Random Effect Model (REM)}

$$
\mathrm{H}_{1} \text { : Fixed Effect Model (FEM) }
$$

Dengan ketentuan apabila nilai probabilitas $>0,05$, maka $\mathrm{H}_{0}$ diterima dan tolak $\mathrm{H}_{1}$ yang artinya model yang tepat menggunakan pendekatan random effect. Namun apabila nilai probabilitas < 0,05 , maka $\mathrm{H}_{0}$ ditolak dan menerima $\mathrm{H}_{1}$ yang artinya model yang tepat adalah menggunakan pendekatan fixed effect.

Penelitian ini menggunakan data runtutan waktu (time series) dengan data kuartal mulai dari kuartal I tahun 2011 hingga kuartal II tahun 2016. Objek penelitian ini adalah empat bank umum syariah hasil pemisahan dari bank induk konvensional dengan melalui proses pemisahan unit usaha syariah terlebih dahulu dan telah terdaftar di Bank Indonesia, yaitu BNI Syariah, BJB Syariah, BRI Syariah dan Bank Syariah Bukopin. Untuk mengukur 
pengaruh metode pemisahan terhadap ROA bank umum syariah hasil pemisahan, maka akan menggunakan variabel dummy. Persamaan regresi data panel pada penelitian ini adalah:

$\mathrm{ROA}_{\text {it }}=\alpha+\mathrm{b}_{1} \mathrm{D}_{\mathrm{it}}+\mathrm{b}_{2} \mathrm{NPF}_{\mathrm{it}}$

$+\mathrm{b}_{3} \mathrm{BOPO}_{\mathrm{it}}+\mathrm{b}_{4} \mathrm{CAR}_{\mathrm{it}}+\mathrm{b}_{5} \mathrm{FDR}_{\mathrm{it}}+$ $\varepsilon_{\mathrm{it}}$

\section{Keterangan :}

$\mathrm{ROA}_{\mathrm{it}}=$ Return On Asset pada unit observasi ke-i dan waktu ke-t

$\mathrm{D}_{\text {it }} \quad=$ Variabel dummy metode pemisahan pada unit ke-i dan waktu ke-t

Dimana: $0 \quad=$ Tipe 1 ; dan $1=$ Tipe 2

1 = tipe pemisahan murni; 2 = tipe pemisahan akuisisi, konversi dan merger

$\mathrm{NPF}_{\text {it }}=$ Net Profit Finance pada pada unit ke-i dan waktu ke-t

$\mathrm{BOPO}_{\mathrm{it}}=$ Biaya Operasional Pendapatan Operasional pada unit observasi ke-i dan waktu ke-t
$\mathrm{CAR}_{\text {it }}=$ Capital Adequacy Ratio pada unit observasi ke-i dan waktu ke-t

$\mathrm{FDR}_{\mathrm{it}} \quad=$ Financing to Deposit Ratio pada unit observasi ke-i dan waktu ke-t

$\varepsilon_{\text {it }}=$ Komponen error pada unit observasi ke-1 dan waktu ke-t

\section{HASIL}

DAN

\section{PEMBAHASAN}

Hal pertama yang dilakukan ialah melakukan uji Chow untuk menentukan apakah model yang digunakan apakah model common effect atau model efek tetap. Tabel 3 memperlihatkan hasil uji Chow dimana nilai probabilitas sebesar 0.0188. Hal ini menunjukkan bahwa Hipotesis nul yang menyatakan common effect model ditolak. Oleh karenanya yang dipilih ialah model efek tetap (fixed effect model).

Tabel 3. Hasil Uji Chow

\begin{tabular}{|c|c|c|c|}
\hline Redundant Fixed $\mathrm{E}$ & & & \\
\hline Test period fixed ef & & & \\
\hline Effects Test & Statistic & d.f. & Prob. \\
\hline Period $\mathrm{F}$ & 2.000108 & $(21,61)$ & 0.0188 \\
\hline Period Chi-square & 46.101188 & 21 & 0.0012 \\
\hline
\end{tabular}


Selanjutnya kita akan melakukan uji Haussman untuk menentukan apakah memilih model efek acak (random effect model) atau model efek tetap (fixed effect model). Hasil uji Haussman memperlihatkan nilai probabilitas $1.000>$ tingkat signifikansi (a $=0,05)$, maka $\mathrm{H}_{0}$ tidak dapat ditolak (don't reject $\left.H_{0}\right)$. Oleh karenanya dapat dikatakan bahwa model efek acak (random effect model) lebih tepat digunakan. memilih salah satu dari kedua metode pemisahan, baik itu metode pemisahan murni maupun metode pemisahan akuisisi, konversi dan merger tergantung pada kebutuhan dan kesiapan unit usaha syariah dan bank induk konvensional.

Terdapat dua variabel bebas yang juga tidak memiliki pengaruh terhadap Return On Asset (ROA) bank umum syariah hasil pemisahan, yaitu Capital Adequacy Ratio (CAR) dan Financing to Deposit Ratio (FDR).

Tabel 4. Hasil Uji Hausman

\begin{tabular}{|c|c|c|c|}
\hline \multicolumn{3}{|c|}{ Correlated Random Effects - Hausman Test } & \\
\hline \multicolumn{2}{|c|}{ Test period random effects } & & \\
\hline Test Summary & $\begin{array}{l}\text { Chi-Sq. } \\
\text { Statistic }\end{array}$ & Chi-Sq. d.f. & Prob. \\
\hline Period random & 0.000000 & 5 & 1.0000 \\
\hline
\end{tabular}

Berdasarkan model random effect pada Tabel 5 dapat dilihat bahwa nilai probabilitas variabel dummy metode pemisahan sebesar 0,1244. Nilai tersebut lebih besar dari $\mathrm{a}=$ $0,05(0,1244>0,05)$, sehingga dapat dikatakan bahwa metode pemisahan baik itu pemisahan murni atau pemisahan dengan cara akuisisi, konversi dan merger tidak berpengaruh secara signifikan terhadap Return On Asset (ROA) bank umum syariah hasil pemisahan. Unit usaha syariah yang hendak melakukan pemisahan dapat
Sedangkan dua variabel bebas lainnya, yaitu Non Performing Finance (NPF) dan BOPO menunjukkan memiliki pengaruh negatif terhadap Return On Asset (ROA) bank umum syariah hasil pemisahan. Hal ini menunjukkan semakin tinggi nilai rasio Non Performing Finance (NPF), maka akan semakin kecil nilai rasio Return On Asset (ROA). Begitu juga semakin tinggi nilai rasio $\mathrm{BOPO}$, maka akan menyebabkan menurunnya Return On Asset (ROA) bank umum syariah hasil pemisahan. Hamid (2015) 
memaparkan bahwa kebijakan pemisahan berpengaruh signifikan terhadap Return On Asset. Hal ini dapat disebabkan karena peningkatan total aset bank umum syariah setelah melakukan pemisahan tidak dibarengi dengan peningkatan pada pendapatan yang diperoleh, sehingga laba yang dihasilkan pun tidak optimal atau dapat disebabkan karena saat melakukan pemisahan tentu akan meningkatkan jumlah aset. Peningkatan aset tersebut juga akan mengakibatkan meningkatnya beban depresiasi, peningkatan beban ini yang menjadikan laba tidak optimal.

Al Arif (2014) yang memperlihatkan bahwa tipe pemisahan tidak memiliki pengaruh terhadap total aset empat bank umum syariah hasil pemisahan. Hasil studi ini menunjukkan bahwa setiap unit usaha syariah yang hendak melakukan pemisahan dapat memilih salah satu dari kedua tipe pemisahan tergantung kepada kebutuhan dari institusi yang bersangkutan. Al Arif dan Haribowo (2016) menemukan pula bahwa tipe pemisahan tidak berpengaruh terhadap laba pada bank umum syariah hasil pemisahan. 
Tabel 5. Hasil Random Effect Model

\begin{tabular}{|c|c|c|c|c|}
\hline \multicolumn{3}{|c|}{ Dependent Variable: ROA } & & \\
\hline \multicolumn{4}{|c|}{ Method: Panel EGLS (Period random effects) } & \\
\hline \multicolumn{3}{|c|}{ Sample: 2011Q1 2016Q2 } & & \\
\hline \multicolumn{3}{|l|}{ Periods included: 22} & & \\
\hline \multicolumn{3}{|c|}{ Cross-sections included: 4} & & \\
\hline \multicolumn{4}{|c|}{ Total panel (balanced) observations: 88} & \\
\hline \multicolumn{5}{|c|}{ Swamy and Arora estimator of component variances } \\
\hline Variable & Coefficient & Std. Error & t-Statistic & Prob. \\
\hline $\mathrm{C}$ & 9.587571 & 0.507040 & 18.90889 & 0.0000 \\
\hline D_METODE & -0.103566 & 0.066711 & -1.552465 & 0.1244 \\
\hline CAR & -0.009170 & 0.006934 & -1.322593 & 0.1896 \\
\hline NPF & -0.083294 & 0.018234 & -4.568094 & 0.0000 \\
\hline BOPO & -0.085230 & 0.005032 & -16.93702 & 0.0000 \\
\hline \multirow[t]{3}{*}{ FDR } & -0.006064 & 0.003244 & -1.869267 & 0.0652 \\
\hline & \multicolumn{2}{|c|}{ Effects Specification } & & \\
\hline & & & S.D. & Rho \\
\hline \multicolumn{2}{|l|}{ Period random } & & 0.087645 & 0.1257 \\
\hline \multicolumn{3}{|l|}{ Idiosyncratic random } & 0.231185 & 0.8743 \\
\hline & \multicolumn{2}{|c|}{ Weighted Statistics } & & \\
\hline R-squared & 0.870319 & \multicolumn{2}{|c|}{ Mean dependent var } & 0.667536 \\
\hline Adjusted R-squared & 0.862412 & \multicolumn{2}{|c|}{ S.D. dependent var } & 0.650367 \\
\hline S.E. of regression & 0.241240 & \multicolumn{2}{|c|}{ Sum squared resid } & 4.772126 \\
\hline F-statistic & 110.0644 & \multicolumn{2}{|c|}{ Durbin-Watson stat } & 1.109178 \\
\hline \multirow[t]{2}{*}{ Prob(F-statistic) } & 0.000000 & & & \\
\hline & \multicolumn{2}{|c|}{ Unweighted Statistics } & & \\
\hline R-squared & 0.862990 & \multicolumn{2}{|c|}{ Mean dependent var } & 0.837727 \\
\hline Sum squared resid & 5.534992 & \multicolumn{2}{|c|}{ Durbin-Watson stat } & 1.069765 \\
\hline
\end{tabular}

Hasil empiris yang telah dilakukan menunjukkan bahwa tipe pemisahan -baik pemisahan murni maupun pemisahan dengan akuisisi, konversi, dan merger- tidak berpengaruh terhadap nilai aset, dana pihak ketiga dan jumlah pembiayaan. Hasil ini berbeda dengan Rizqullah (2013) yang menemukan bahwa metode pemisahan UUS dengan cara membentuk badan/perusahaan baru adalah alternatif pendirian bank syariah yang paling 
baik/sesuai. Urutan alternatif pilihan strategi selanjutnya adalah pemisahan dengan menggunakan badan/ perusahaan yang sudah ada. Kedua metode pemisahan dipengaruhi oleh jenis elemenelemen yang berbeda. Metode pemisahan dengan membentuk badan baru dipengaruhi oleh elemen-elemen: budaya perusahaan, program komunikasi, respon nasabah, delivery channel, respon pesaing, dan perpajakan. Sedangkan metode pemisahan dengan badan usaha yang sudah ada dipengaruhi oleh elemenelemen: pengalihan status pegawai, sistem pelaporan dan pembukuan, sistem IT, perpajakan, respon regulator dan due diligence. Perbedaan elemenelemen tersebut menunjukkan bahwa prioritas permasalahan yang terdapat pada kedua metode tersebut juga berbeda (Rizqullah, 2013).

Dewati (2015) dalam penelitiannya menjelaskan bahwa berdasarkan faktor-faktor yang menjadi pertimbangan dalam pemilihan metode pemisahan, dapat disimpulkan dari 23 variabel yang digunakan dalam penelitian ini dapat dikelompokkan atau direduksi menjadi 6 kelompok/faktor yang menjadi pertimbangan dalam proses pemisahan. Keenam faktor tersebut yaitu: (1) faktor perencanaan strategis atau strategic planning; (2) kemudahan atau practicality proses pemisahan; (3) kepentingan stakeholder atau stakeholders concern; (4) orientasi internal; (5) pengelolaan sistem IT atau IT drivers; (6) faktor infrastruktur. Terdapat perbedaan atas faktor yang lebih dipertimbangkan dalam implementasi masingmasing metode pemisahan. Untuk implementasi metode pemisahan dengan badan usaha baru, faktor yang lebih dipertimbangkan adalah practicality, infrastruktur dan strategic planning, sedangkan untuk implementasi metode pemisahan dengan badan yang sudah ada, faktor yang lebih dipertimbangkan IT driven, stakeholders concern, dan orientasi internal. Keenam faktor yang menjadi pertimbangan tersebut dirumuskan sebagai rekomendasi kepada berbagai pihak di dalam sektor perbankan, terutama jajaran manajemen Unit Usaha Syariah (UUS), dalam menetapkan metode pemisahan yang dinilai sesuai dengan kondisi unit bisnis syariah serta mampu memaksimalkan kinerja unit syariah setelah implementasi proses pemisahan atas unit syariah tersebut.

pemisahan merupakan kewajiban yang harus dilakukan bank umum konvensional yang telah membuka unit 
usaha syariah. Kebijakan pemisahan ini dirasa sangat diperlukan mengingat kesadaran masyarkat akan bank syariah terus meningkat seiring berjalannya waktu, sehingga membuat sebagian nasabah masih meragukan kemurnian prinsip syariah pada unit usaha syariah yang beroperasi di bawah naungan bank umum konvensional. Karena terdapat perbedaan prinsip dan karakteristik antara sistem perbankan syariah dan perbankan konvensional, maka sistem konvensional dan sistem syariah harus berjalan masingmasing. Dengan dilakukannya pemisahan manajemen bank umum konvensional akan lebih fokus pada kompetensi utamanya dan bank umum syariah dapat fokus dalam menjalankan bisnis syariahnya secara lebih independen.

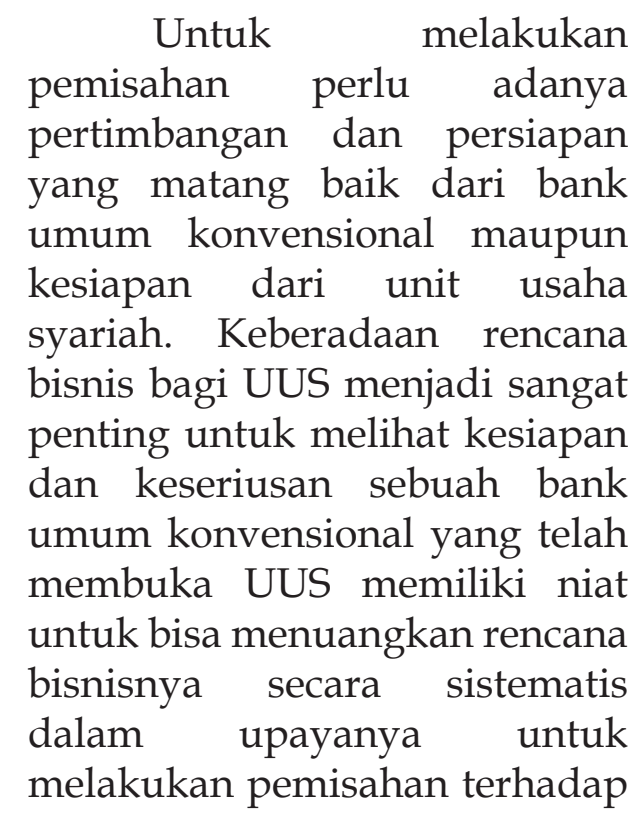

unit usaha syariahnya. Dengan pertimbangan dan kesiapan yang matang, maka akan berdampak baik pula untuk bank umum syariah pasca melakukan pemisahan. Siswantoro (2014) menjelaskan bank umum syariah hasil pemisahan dapat mengoptimalkan suntikan permodalan dari bank induk konvensional untuk dapat meningkatkan pertumbuhan bank tersebut. Al Arif (2015) menjelaskan bahwa kebijakan pemisahan secara umum justru menyebabkan industri perbankan syariah menjadi kurang efisien dibandingkan dengan kondisi sebelum pemisahan terjadi. Hal ini dapat dilihat pada kenaikan rasio BOPO pada periode awal pemisahan. Karena ketika unit usaha syariah tersebut telah memisahkan diri, maka biayabiaya yang semula ditanggung bank induk konvensional kini harus ditanggung sendiri oleh bank umum syariah hasil pemisahan. Beberapa biaya yang harus ditanggung sendiri oleh bank umum syariah hasil pemisahan antara lain: pertama, biaya terkait dengan pembiayaan seperti biaya penagihan, biaya hukum, biaya penyisihan piutang tidak tertagih, dan biaya-biaya lainnya. Kedua, biaya adminitrasi dan umum. Sebagai suatu entitas bisnis yang baru berdiri secara mandiri tentu masih mengeluarkan banyak biaya terkait dengan 
administrasi dan umum. Ketiga, biaya teknologi. Hampir seluruh bank umum syariah hasil pemisahan membuat suatu sistem teknologi tersendiri, hal ini mengakibatkan pada kenaikan biaya operasional dari bank syariah yang bersangkutan.

Menurut Tubke (2004) terdapat beberapa faktor yang mempengaruhi dalam proses pemisahan (spin-off). Pertama, faktor yang terkait dengan aktivitas bisnis, faktor ini terkait dengan ukuran perusahaan dan perbedaan sektor bisnis antara perusahaan induk dengan perusahaan anaknya. Apabila faktor pertama ini dikaitkan dengan unit usaha syariah dapat diposisikan sebagai perusahaan anak dan bank konvensional sebagai perusahaan induk. Kedua, faktor yang terkait dengan organisasi dan pengelolaan perusahaan. Ketiga, faktor yang terkait dengan hubungan dan dukungan. Terdapat tiga pola hubungan yang mungkin tercipta antara perusahaan induk dan perusahaan anak yang melakukan pemisahan, yaitu hubungan pasar (marketrelatedness), hubungan produk (product relatedness), dan hubungan teknologi (technologyrelatedness). Keempat, faktor transfer atau pengalihan berupa transfer pengalaman dari perusahaan induk kepada perusahan anaknya. Kelima, faktor terkait dengan motivasi.
Keenam, faktor terkait dengan lingkungan bisnis baik berupa karakteristik lingkungan bisnis regional maupun legal.

$\mathrm{K}$ e b i j a k a n pemisahan unit usaha syariah menjadi bank umum syariah dapat dijadikan sebagai salah satu strategi bisnis untuk meningkatkan perkembangan industri perbankan syariah di Indonesia. Pemisahan harus dilakukan dengan pertimbangan yang matang. Otoritas Jasa Keuangan (OJK) sebagai regulator sebaiknya juga memperhatikan perkembangan industri perbankan syariah dan fokus untuk meningkatkannya tidak hanya fokus untuk mendorong UUS untuk segera melakukan pemisahan, karena dalam beberapa tahun ini perkembangan industri perbankan syariah sedang mengalami penurunan. Selain itu OJK diharapkan dapat memeriksa setiap rencana bisnis UUS untuk menilai sejauh mana rencana bisnis UUS disusun secara matang agar dapat mengetahui keseriusan dan persiapan UUS untuk melakukan pemisahan.

\section{PENUTUP}

Hasil analisis data menunjukkan bahwa metode pemisahan Unit Usaha Syariah (UUS) menjadi Bank Umum 
Syariah (BUS) tidak memiliki pengaruh yang signifikan terhadap Return On Asset (ROA) bank umum syariah hasil pemisahan Hal ini menunjukkan bahwa unit usaha syariah yang hendak melakukan pemisahan dapat memilih salah satu dari dua metode pemisahan, baik itu metode pemisahan murni ataupun metode pemisahan akuisisi, konversi dan merger tergantung kebutuhan dan kondisi internal unit usaha syariah serta kebijakan dari bank induk konvensional. Melihat perbedaan prinsip dan karakteristik pada kegiatan operasional yang dilakukan antara bank konvensional dan bank syariah, maka kebijakan pemisahan ini sangat perlu dilakukan agar kegiatan syariah dan konvensional dapat berjalan masing-masing. Dengan melakukan pemisahan dapat mendorong berjalannya praktik perbankan syariah yang mengedepankan prinsip syariah tanpa intervensi bank induk konvensional. 


\section{DAFTAR PUSTAKA}

Al Arif, M.N.R. (2014). Spin-off and Its Impact on The Third Party Funds of Indonesian Islamic Banking Industry. Economic Jurnal of Emerging Markets. Vol. 6 (1): 50-55

Al Arif, M.N.R. (2014). Tipe Pemisahan dan Pengaruhnya Terhadap Nilai Aset Bank Umum Syariah Hasil Pemisahan. Kinerja. Vol. 18 (2): 168-179

Al Arif, M.N.R. (2015). Keterkaitan Kebijakan Pemisahan terhadap Tingkat Efisiensi pada Industri Perbankan Syariah di Indonesia. Jurnal Keuangan dan Perbankan. Vol.19 (2): 295-304

Al Arif, M.N.R. (2015). The Effect of Spin-Off Policy on Financing Growth in Indonesia Islamic Industry. Al-Ulum. Vol. 15 (1): 173-184.

Al Arif, M.N.R dan Haribowo, I. (2016). Tipe Pemisahan dan Pengaruhnya Terhadap Laba Pada Bank Umum Syariah Hasil Pemisahan. Jurnal Keuangan dan Perbankan. Vol. 20, No. 3: 479486.

Dewati, H.R. (2015). Pemilihan Metode Spin Off Unit Bisnis Syariah dengan Pendekatan Analisa Faktor (Studi PT BNI Syariah dan PT Bank Syariah BRI). (Tesis Tidak Dipublikasikan). Bogor: Institut Pertanian Bogor.

Hamid, A. (2015). The Impact of Spin-off Policy to the Profitability on Indonesia Islamic Banking Industry. Al-Iqtishad: Jurnal Ilmu Ekonomi Syariah (Journal of Islamic Economics). Vol.7(1): 117126.

Kiswono, Bambang. (2012). Spin Off Unit Usaha Syariah (UUS), Kendala dan Strategi Penyelesaiannya. (Makalah Tidak Dipublikasikan). Jakarta: Bank Indonesia

Nasuha, A. (2012). Dampak Kebijakan Spin-Off Terhadap Kinerja Bank Syariah. Al-Iqtishad: Jurnal Ilmu Ekonomi Syariah (Journal of Islamic Economics). Vol. 4 (2): 241-158

Ramdani, A. (2015). Pengaruh Kebijakan Pemisahan Terhadap Laba 
Pada Bank BNI Syariah, Etikonomi: Jurnal Ekonomi. Vol. 14 (1): 17-34.

Rizqullah. (2013). Pemilihan Metode Spin-Off Unit Usaha Syariah Bank Umum Konvensional Menjadi Bank Umum Syariah di Indonesia. (Disertasi Tidak Dipublikasikan). Jakarta: IEF Trisakti.

Siswantoro, D. (2014). Analysis of Islamis bank's performance and strategy after spin-off as Islamic full-fledged scheme in Indonesia. Procedia Social and Behavioral Sciences. Vol. 164: 4148.

Tubke, Alexander. (2004). Success Factors of Corporate Spin-Offs. USA: Springer.

Umam, K. (2010). Peningkatan Ketaatan Syariah Melalui Pemisahan (Spin-off) Unit Usaha Syariah Bank Umum Konvesional. Mimbar Hukum. Vol.22 No.3: 607-624. 